\title{
Phosphate-Solubilizing Enterobacter ludwigii AFFR02 and Bacillus megaterium Mj1212 Rescues Alfalfa's Growth under Post-Drought Stress
}

\author{
Sang-Mo Kang 1,2,+, Muhammad-Aaqil Khan ${ }^{1,+}{ }^{+}$, Muhammad Hamayun ${ }^{3}$, Lee-Rang Kim ${ }^{1}$, Eun-Hae Kwon ${ }^{1}$, \\ Yo-Sep Kang ${ }^{1}$, Ki-Yong Kim ${ }^{4}$, Jae-Jeong Park ${ }^{1}$ and In-Jung Lee ${ }^{1, *}$ \\ 1 Department of Applied Biosciences, Kyungpook National University, Daegu 41566, Korea; \\ sangmo@knu.ac.kr (S.-M.K.); aqil_bacha@knu.ac.kr (M.-A.K.); pwpw102@knu.ac.kr (L.-R.K.); \\ rnjsdmsgo10@knu.ac.kr (E.-H.K.); alfm4545@knu.ac.kr (Y.-S.K.); wowjd4391n@naver.com (J.-J.P.) \\ 2 Institute of Agricultural Science and Technology, Kyungpook National University, Daegu 41566, Korea \\ 3 Department of Botany, Abdul Wali Khan University, Khyber Pakhtunkhwa, Mardan 23200, Pakistan; \\ hamayun@awkum.edu.pk \\ 4 National Institute of Animal Science, Rural Development Administration (RDA), Cheonan 31000, Korea; \\ kimky77@korea.kr \\ * Correspondence: ijlee@knu.ac.kr; Tel.: +82-53-950-5708; Fax: +82-53-958-6880 \\ + These authors contributed equally to this work.
}

\section{check for} updates

Citation: Kang, S.-M.; Khan, M.-A.; Hamayun, M.; Kim, L.-R.; Kwon, E.-H.; Kang, Y.-S.; Kim, K.-Y.; Park, J.-J.; Lee, I.-J. Phosphate-Solubilizing Enterobacter ludwigii AFFR02 and Bacillus megaterium Mj1212 Rescues Alfalfa's Growth under Post-Drought Stress. Agriculture 2021, 11, 485. https://doi.org/10.3390/ agriculture11060485

Academic Editor: Guodong Liu

Received: 12 April 2021

Accepted: 21 May 2021

Published: 24 May 2021

Publisher's Note: MDPI stays neutral with regard to jurisdictional claims in published maps and institutional affiliations.

Copyright: (C) 2021 by the authors. Licensee MDPI, Basel, Switzerland. This article is an open access article distributed under the terms and conditions of the Creative Commons Attribution (CC BY) license (https:/ / creativecommons.org/licenses/by/ $4.0 /)$.
Abstract: Drought stress is a prevalent environmental stress that adversely affects agricultural industries worldwide. In this study, bacterial isolates, AFFR02 and Mj1212, showed tolerance to polyethylene glycol-induced (PEG) drought stress (approximately 15\%) and possess strong phosphate-solubilizing capacity. Moreover, we investigated the plant growth attributes, chlorophyll content, and ion uptake in alfalfa plants (Medicago sativa L) inoculated with isolates AFFR02 and Mj1212 under drought stress. We observed that drought stress drastically affects alfalfa's growth attributes: shoot length: SL $(24.88 \%)$, root length: RL $(29.62 \%)$, shoot fresh weight: SFW (49.62\%), root fresh weight: RFW (45.09\%), stalk diameter: SD (52.84\%), and chlorophyll content: CC (19.2\%). However, in bacterial-inoculated alfalfa plants, the growth attributes significantly recovered were SL (12.42\%), RL (21.30\%), SFW (50.74\%), RFW (46.42\%), SD (76.72\%), and CC (17.98\%). In drought-stressed alfalfa plants, we observed a significant decrease in the relative water content $(7.45 \%)$, whereas there was an increase in electrical conductivity $(68.87 \%)$ and abscisic acid contents (164.42\%). Antioxidant analysis showed a significant increase in total phenolic content $(46.08 \%)$, DPPH-scavenging activity (39.66\%), total flavonoid (13.68\%), and superoxide dismutase $(28.51 \%)$ in alfalfa treated with drought stress and bacterial isolates AFFR02 and Mj1212 simultaneously. Moreover, an increase in inductively coupled plasma (ICP) analysis of potassium (17.98\%), phosphorous $(11.14 \%)$, calcium $(3.07 \%)$, and magnesium $(6.71 \%)$ was recorded for bacteria-inoculated alfalfa plants under drought stress. In conclusion, bacterial isolates AFFR02 and Mj1212 enhance alfalfa growth under drought stress. Therefore, the isolates could be used as potential candidates in smart-climate agricultural practices in drought-stricken areas worldwide.

Keywords: phosphate solubilization; bacterial isolates; drought stress; growth attributes; antioxidants

\section{Background}

Environmental factors, such as drought, salinity, temperature, heavy metals, and freezing stress, are important agricultural problems that impose stress on crop plants and cause widespread crop losses worldwide [1-9]. The continuous increase in temperature and water scarcity is increasing the frequency of severe drought conditions [10]. Drought stress is defined as the scarcity of water available to plants, and $50 \%$ of the world's arid or semiarid land is subjected to drought stress [11]. Drought stress intervenes in the normal biochemical, physiological, and morphological processes of plants by reducing leaf size, 
stem extension, root proliferation, photosynthesis, nutrient, and water relation [10,12-14]. Mineral nutrients are essential chemical elements for plant growth and development [15]. Drought stress causes nutrient deficiencies and interrupts the supply of essential trace elements because the physicochemical properties of soil reduce the mobility and absorbance of individual nutrients $[15,16]$. A decrease in the availability of nutrients leads to poor growth, development, and productivity of crop plants under drought stress [17]. Among essential nutrients, phosphorous is a vital macronutrient least available to plants and plays a significant role in growth and metabolic activities [18].

It is widely recognized that the perception of abiotic stress triggers the interaction of signal transduction cascades with the pathways transduced by phytohormones and defense antioxidants [1]. The fluctuation of stress-responsive plant hormones plays a central role in regulating growth response under stress conditions [19-22]. Among various phytohormones, abscisic acid (ABA) is called the stress hormone [23,24], and the level of ABA increases via $A B A$ biosynthesis in harsh environments, including drought stress $[12,25,26]$. $A B A$ is a primary phytohormone regulating various physiological processes, such as stomatal closure and favoring the maintenance of root growth by optimizing water uptake during drought stress [1,25]. Drought stress also causes membrane damage and stomatal closure by enhancing metabolite flux and generating reactive oxygen species, leading to increased oxidative load and severely damaging biological macromolecules [1,27]. To maintain cellular redox potential, plants tend to accumulate more antioxidants to mitigate cellular damage and stress conditions [28].

So far, different strategies have been developed to improve drought stress tolerance in crop plants, including legumes $[1,29,30]$. An alternative strategy to improve drought tolerance may be introducing drought-tolerant microbes that enhance crop growth and development under drought stress [11,13,29-33]. Numerous studies have shown that plant growth-promoting drought-tolerant bacteria is a relatively simple low-cost alternative strategy, and beneficially impacts growth attributes, biomass, and chlorophyll content (CC) under drought stress [11-13,32,34-36]. Plants can actively engage microorganisms in the surrounding environment by exerting positive effects on plant performance and stress resilience, including drought stress [12,34,37]. Previously-reported drought-tolerant isolates solubilized more phosphorus under stress conditions compared with normal conditions $[18,38]$. P-solubilizing bacteria have attracted attention because of their agroeconomic environmental-friendly approach, safer to use as P-fertilizer instead of using expensive P-chemical fertilizers [38].

Alfalfa (Medicago sativa L.) is a perennial legume that is mostly grown on grassland, pastures, and many places globally [5,39]. Alfalfa has a great agronomic importance and is grown on 30 million hectares of land worldwide [40]. Alfalfa is known as the queen of forage because of its high yield capacity, abundant forage for animals, and its ability to improve soil fertility $[5,41]$. It is also used as biofuel, and in pharmaceutical factories, it is used to produce monoclonal antibodies, industrial proteins, and enzymes, such as alpha-amylase, cellulose, and lignin peroxidase [42]. Alfalfa is also consumed by humans in sprout because of its highly nutritious low fiber, crude protein, important minerals, and amino acids [43]. Drought stress is a significant abiotic stress affecting the productivity and annual yield of alfalfa [44]. Bouizgaren et al. [45] reported a $49 \%$ decrease in biomass and photosynthesis in alfalfa due to water stress. Various researchers previously reported drought stress tolerance through various organic fertilizers and chemicals [46-48]. However, chemical fertilizer use leads to a marked deterioration of agricultural soil and underground water quality [49,50]. Using biofertilizers instead of fertilizers and chemicals improves plant growth by sustaining environmental health and soil productivity $[49,51,52]$. This study examines the growth attributes of alfalfa plants inoculated with drought stresstolerant AFFR02 and MJ122 under control and post-drought stress. Furthermore, we have also determined the endogenous $\mathrm{ABA}$, and different antioxidant and mineral uptake regulation in inoculated and non-inoculated alfalfa under control and post-drought stress. 


\section{Materials and Methods}

\subsection{Isolation, Screening, and Identification}

Rhizospheric bacteria were isolated from Seosan, Chungcheongnam-do Province, and Geongbuk-do Province in the Republic of Korea, according to the detailed method of $[53,54]$. All isolates were screened for different PEG $(0 \%, 5 \%, 10 \%$, and $15 \%)$ concentrations and phosphate solubilization. To elevate the drought tolerance of isolated rhizospheric bacteria, different PEG $(0 \%, 5 \%, 10 \%$, and $15 \%)$ concentrations were added in Luria broth (LB) media and kept in a shaking incubator $\left(120 \mathrm{rpm} ; 28^{\circ} \mathrm{C}\right)$ for 4 day. The optical density (OD) $(600 \mathrm{~nm})$ was taken at a regular interval of $12 \mathrm{~h}$ for $4 \mathrm{~d}$ by using a spectrophotometer (Shimadzu, Kyoto, Japan). The National Botanical Institute Phosphate media $(0.5 \%)$ was used to inoculate isolated microbes, and they were incubated at $30{ }^{\circ} \mathrm{C}[55,56]$. The bacterial isolate formed a cleared halo on plates, indicating phosphate solubilization. For the phosphate-solubilizing ability, bacterial isolates were inoculated into $100 \mathrm{~mL}$ of optimum medium containing tricalcium phosphate at $35^{\circ} \mathrm{C}$. Quantitative spectrophotometric analysis of soluble phosphate was performed according to the described method of Kang et al. [57]. Alternatively, the $\mathrm{pH}$ was measured daily; the $\mathrm{pH}$ of the medium was recorded using $\mathrm{pH}$ meter equipped with a glass electrode. Furthermore, for bacterial identification, the $16 \mathrm{~S}$ rRNA gene was amplified using general bacterial primers $27 \mathrm{~F}$ and 1492R. The nucleotide sequences of PCR products were compared using the BLAST NCBI and EzTaxon program. A phylogenetic tree was constructed following the neighbor-joining method using MEGA v.7 and was sent to the GenBank database for accession number. Isolate Mj1212 had phosphate-solubilizing activity and promotes mustard plant growth under normal conditions [58].

\subsection{Plant Growth-Promoting Effect of Isolate AFFR02 and MJ1212 on Alfalfa under Normal and Post-drought Stress}

Alfalfa seeds were purchased from Nature \& Kids Korea Ltd. and sown in trays filled with autoclaved horticultural soil (which contained $51.5 \%$ coco peat, $10 \%$ peat moss, $13 \%$ vermiculite, $15 \%$ perlite, $10 \%$ zeolite, humic acid, $0.1 \%$ fertilizer, and $0.4 \%$ fungus-free bio-soil; Shinsung Mineral Co., Ltd., Goesan, Korea). After 2 weeks of germination, one seedling was transferred to each pot $(100 \mathrm{~mm}$ diameter $\times 90 \mathrm{~mm}$ depth) and grown in a greenhouse. The experiment was conducted in the Kyungpook National University greenhouse, at Daegu, under natural light with controlled environmental conditions: day/night temperature: $28 \pm 3{ }^{\circ} \mathrm{C} / 25 \pm 3{ }^{\circ} \mathrm{C}$, with relative humidity of $60 \%-70 \%$. The experiment was conducted in a completely randomized design, with each treatment replicated 10 times throughout the study. The experimental design included (a) no stress: $(200 \mathrm{~mL}$ water per week), (b) $200 \mathrm{~mL}$ of cell suspension of isolate MJ1212 $\left(2.75 \times 10^{7} \mathrm{CFU} / \mathrm{mL}\right)$ and AFFR02 (2.08 $\left.\times 10^{7} \mathrm{CFU} / \mathrm{mL}\right) /$ week), (c) drought stress: (50 mL water per week), and (d) bacterial-treated (50 mL cell suspension of isolate MJ1212 and AFFR02/week). After 2 weeks of drought stress, alfalfa plants were treated with normal water for 3 weeks (postdrought stress). The shoot/root length (SL/RL), shoot/root fresh weight (SFW/RFW), stalk diameter (SD), and CC were measured using a portable chlorophyll meter (SPAD-502, Konica, Japan). For chlorophyll, $\mathrm{a}$ and $\mathrm{b}$ and total carotenoids, the detailed method of Khan et al. [59] was followed using $80 \%$ acetone. Their content was measured spectrophotometrically at wavelengths of $663 \mathrm{~nm}, 465 \mathrm{~nm}$, and $480 \mathrm{~nm}$, respectively.

\subsection{Determination of Leaf Water Potential and Electrolyte Leakage in Alfalfa Plants under Normal and Post-Drought-Stressed Conditions}

Leaf relative water content (RWC) was measured according to a previously described method of Lubna et al. [60]. Individual leaves were collected and weighed (fresh weight; FW) and immersed in distilled water overnight. At the end, turgid weight (TW) was measured and kept in a preheated oven $\left(75^{\circ} \mathrm{C}\right.$ for $48 \mathrm{~h}$ ) to obtain dry weight (DW). The RWC was calculated using the formula: RWC $\%=([\mathrm{FW}-\mathrm{DW}] /[\mathrm{TW}-\mathrm{DW}]) \times 100$. For electrolytic leakage (EL), $500 \mathrm{mg}$ leaves were cut $(5 \mathrm{~mm})$, kept in $10 \mathrm{~mL}$ deionized water in a tube, and placed 
in a water bath at $32{ }^{\circ} \mathrm{C}$. After $2 \mathrm{~h}$, initial EC was measured using an EC1 m. Further plant samples were autoclaved $\left(121^{\circ} \mathrm{C}\right.$ for $\left.15 \mathrm{~min}\right)$, cooled $\left(25^{\circ} \mathrm{C}\right)$, and final EC2 was measured. $\mathrm{EL}$ was estimated using the following formula: $\mathrm{EL}=\mathrm{EC} 1-\mathrm{EC} 2 \times 100$.

\subsection{Endogenous Abscisic Acid Quantification in Alfalfa Plants under Normal and Post-Drought-Stressed Conditions}

Endogenous ABA was quantified and extracted according to a method by Khan et al. [61] and Asaf et al. [62]. ABA was extracted from the aerial parts (freeze-dried plant samples, $0.3 \mathrm{~g}$ ) with $30 \mathrm{~mL}$ extraction solution (95\% isopropanol and $5 \%$ glacial acetic acid), and a chromatograph was run using $10 \mathrm{ng}$ of Me-[2H6]-ABA standard. The suspension was filtered, and the filtrate was concentrated using a rotary evaporator. The residue was suspended in $4 \mathrm{~mL}$ of $1 \mathrm{~N} \mathrm{NaOH}$ solution and rinsed three times with $3 \mathrm{~mL}$ of methylene chloride to eliminate traces of lipophilic materials. After decreasing the $\mathrm{pH}$ of the aqueous phase to 3.5 by adding $6 \mathrm{~N} \mathrm{HCL}$, it was extracted by solvent extraction with ethyl acetate three times. The ethyl acetate extract was then evaporated, and dry residue was resuspended in a phosphate buffer solution $(\mathrm{pH} 8)$ and passed through the polyvinylpolypyrrolidone (PVPP) column. The eluted phosphate buffer solution was partitioned thrice with ethyl acetate (EtOAc) after adjusting the $\mathrm{pH}$ to 3.5 with $6 \mathrm{~N}$ HCL. All three aliquots extracted were pooled and evaporated using a rotary evaporator. Furthermore, the fraction was methylated with diazomethane for detection, and ABA was quantified using gas chromatography-mass spectrometry (GC-MS) $(6890 \mathrm{~N}$ network gas chromatograph, Agilent Technologies). Software from ThermoQuest Corp., Manchester, UK, was used to monitor signal ions $(m / z 162$ and 190 for Me-ABA, and $m / z 166$ and 194 for Me-[2H6]-ABA).

\subsection{Antioxidant Enzyme and Nonenzymatic Activities in Alfalfa Plants under Normal and Post-Drought-Stressed Conditions}

The detailed method of Adhikari et al. [55] was followed to determine polyphenol content. Briefly, samples were extracted with $100 \%$ methanol and measured using a spectrophotometer (Shimadzu, Kyoto, Japan) at $750 \mathrm{~nm}$. For flavonoid content, sample extracts were mixed with double distilled water and then $\mathrm{NaNO}_{2}$ was added. After 5 min, $10 \%$ of $60 \mu \mathrm{L} \mathrm{AlCl}_{3}$ and $1 \mathrm{M} \mathrm{NaOH}$ was added and vortexed. The absorbance reading was taken at $500 \mathrm{~nm}$ using a spectrophotometer, as reported by Adhikari et al. [63]. Superoxide dismutase (SOD) was measured according to the detailed method of Lubna et al. [60]. SOD activity was expressed as enzyme unit (EU) nmol/g. For the DPPH-scavenging activity, a detailed method of Blois [64] was used with some modification. Absorption was measured at $517 \mathrm{~nm}$ using a spectrophotometer and calculated using the following equation: scavenging effect $(\%)=1-\left(\mathrm{Abs}_{\text {sample }}-\mathrm{Abs}_{\text {control }}\right) \times 100$.

\subsection{Determination of Mineral Uptake in Alfalfa Plants under Normal and Post-Drought -Stressed Conditions}

Potassium $(\mathrm{K})$, phosphorous $(\mathrm{P})$, calcium $(\mathrm{Ca})$, and magnesium $(\mathrm{Mg})$ content in the shoots of bacterial-inoculated and non-inoculated post-drought alfalfa plants were investigated according to the detailed method of Sahile et al. [8] and Kang et al. [65], using an inductively coupled plasma mass spectrometer (ICP-MS; Optima 7900DV, Perkin-Elmer, Waltham, MA, USA).

\subsection{Statistical Analysis}

The results of this study were subjected to statistical analysis. The difference in the mean values was compared using Duncan's multiple range test using statistical analysis system (SAS) v.9.3. For graphical presentation, Graph Pad Prism was used. All experiments were conducted in triplicate. 


\section{Results}

\subsection{Isolation and Screening}

Alfalfa plants were collected from Seosan, Chungcheongnam-do Province, Korea. Sixteen rhizospheric bacterial strains were isolated from the roots of alfalfa plants and screened for phosphate-solubilizing activity and PEG stress tolerance. We used isolate Mj1212 with phosphate-solubilizing activity to promote mustard plant growth under normal conditions [58].

\subsection{Screening for Polyethylene Glycol (PEG) Tolerance}

All isolates, including Mj1212, were examined for their ability to grow in different PEG $(0 \%, 5 \%, 10 \%$, and $15 \%)$ concentration stress on LB media. The results from this investigation showed that under approximately $5 \%$ PEG, the growth of all isolates was normal, whereas at 10\% PEG stress, bacterial growth declined. Only three isolates (AFFR02, AFFR07, and Mj1212) showed growth in 15\% PEG LB media (Figure S1).

\subsection{Phosphate-Solubilizing Ability of Isolate AFFR02 and Mj1212}

All isolates were screened for phosphate solubilization. The results showed that on National Botanical Research Institute's phosphate (NBRIP) media plates, the formation of clear halos indicates tricalcium phosphate solubilization capacity. Nine isolates were positive for phosphate solubilization (Figure 1A). Therefore, the phosphate solubilization potential of selected isolates was cross-checked by monitoring the $\mathrm{pH}$ of bacterial-inoculated NBRIP media every $24 \mathrm{~h}$ (Figure 1B). The $\mathrm{pH}$ results showed a decrease in response to phosphate-solubilizing activity of isolate AFFR02 and Mj1212 from an initial $\mathrm{pH}$ of 7.0 to 4.2 after $96 \mathrm{~h}$. In contrast, the P-solubilizing curve showed an increase that confirms the phosphate-solubilizing activity of AFFR02 and Mj1212 in inoculated NBRIP liquid media (Figure 1C).

\subsection{Identification of Effective Rhizospheric Isolate}

Based on their tolerance to PEG and having the highest potential of P-solubilizing characteristic, isolate AFFR02 was selected and identified. To find sequences similar to $16 \mathrm{~S}$ rRNA gene sequence of isolate AFFR02, we checked the database of GenBank, NCBI, and EzTaxon. Identification results of $16 \mathrm{~S}$ rRNA gene sequence of isolate AFFR01 showed close similarity to Enterobacter ludwigii (accession no: Kt261055). Furthermore, the selected sequence nucleotides were sent to the GenBank database and registered with accession number MW345827 for isolate AFFR02 (Figure 2).

\subsection{Beneficial Effect of Isolate AFFR02 and Mj1212 on Alfalfa Plants under Normal and Post-Drought-Stressed Conditions}

Growth attribute, biomass, and CC was investigated in alfalfa plants inoculated with isolate AFFR02 and Mj1212 under normal and post-drought stress. Under normal conditions, an increase in SL (11.24\%; for percentage, mean/average value of AFFR02 and Mj1212 was used), RL (13.2\%), SFW (33.08\%), RFW (43.13\%), SD (15.85\%), and CC (5.20\%) was observed in bacterial-inoculated (AFFR02 and Mj1212) alfalfa plants compared with control plants (only water treated). Alternatively, drought stress inhibited plant growth parameters and a decrease was observed in the growth attributes of post-drought-stressed alfalfa plants (SL (24.88\%), RL (29.62\%), SFW (49.62\%), RFW (45.09\%), SD (52.84\%), and CC (19.2\%)) compared with the control (unstressed/only water-treated plants) (Table 1; Figure 3). However, an increase in the growth attributes, SL (12.42\%), RL (21.30\%), SFW $(50.74 \%), \operatorname{RFW}(46.42 \%), \mathrm{SD}(76.72 \%)$, and CC $(17.98 \%)$, of post-drought-stressed alfalfa plants inoculated with AFFR02 and Mj1212 was observed compared with post-droughtstressed control alfalfa plants (Table 1; Figure 3). Furthermore, a decrease in Chl a (45.09\%), Chl b $(45.11 \%)$, and total carotenoid content $(51.32 \%)$ was observed in post-drought-stressed alfalfa plants compared with the control (unstressed/only water-treated plants). However, alfalfa plants treated with isolate AFFR02 and Mj1212 mitigated drought stress, and an 
increase in Chl a (23.04\%), Chl b (25.89\%), and total carotenoid content $(54.51 \%)$ were observed in post-drought-stressed control alfalfa plants (Table 2).

A

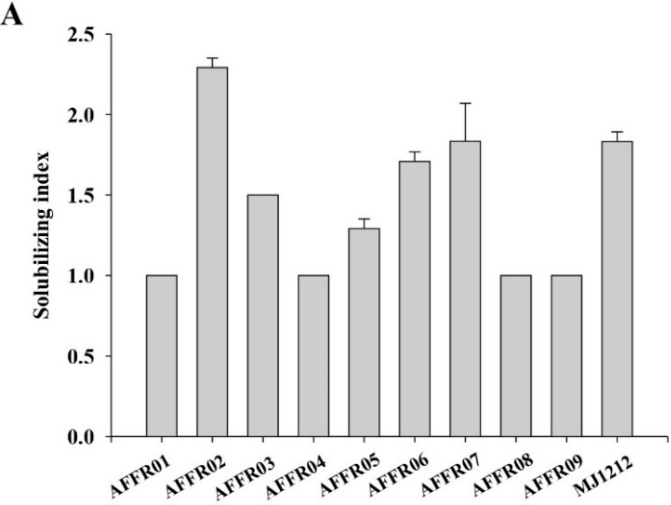

B

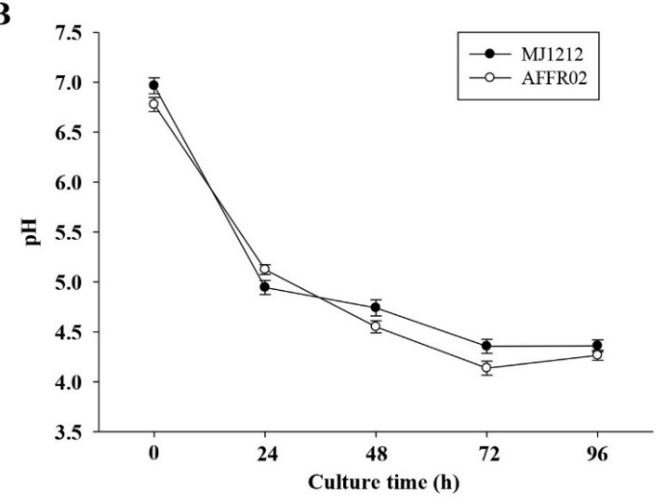

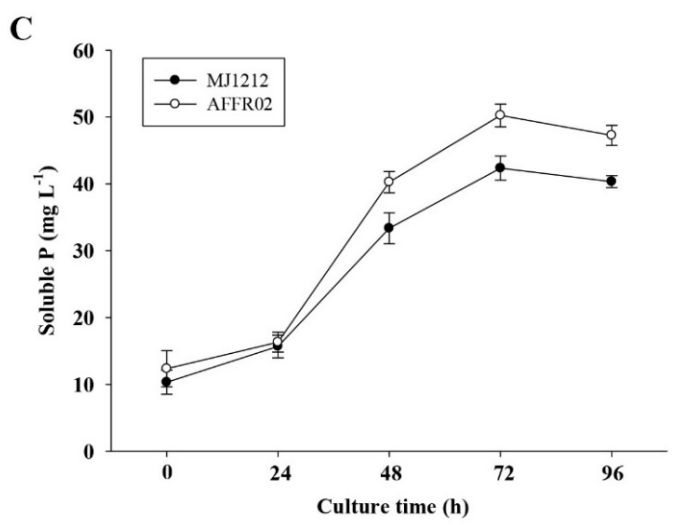

Figure 1. (A) Phosphate solubilization ability of isolated bacteria, (B) $\mathrm{pH}$ value of liquid National Botanical Research Institute's phosphate (NBRIP) medium, and (C) the rate of the halo formation of isolate AFFR02 and MJ1212 in the NBRIP medium. The values given are the mean of three replicates, and error bars indicate standard deviation.
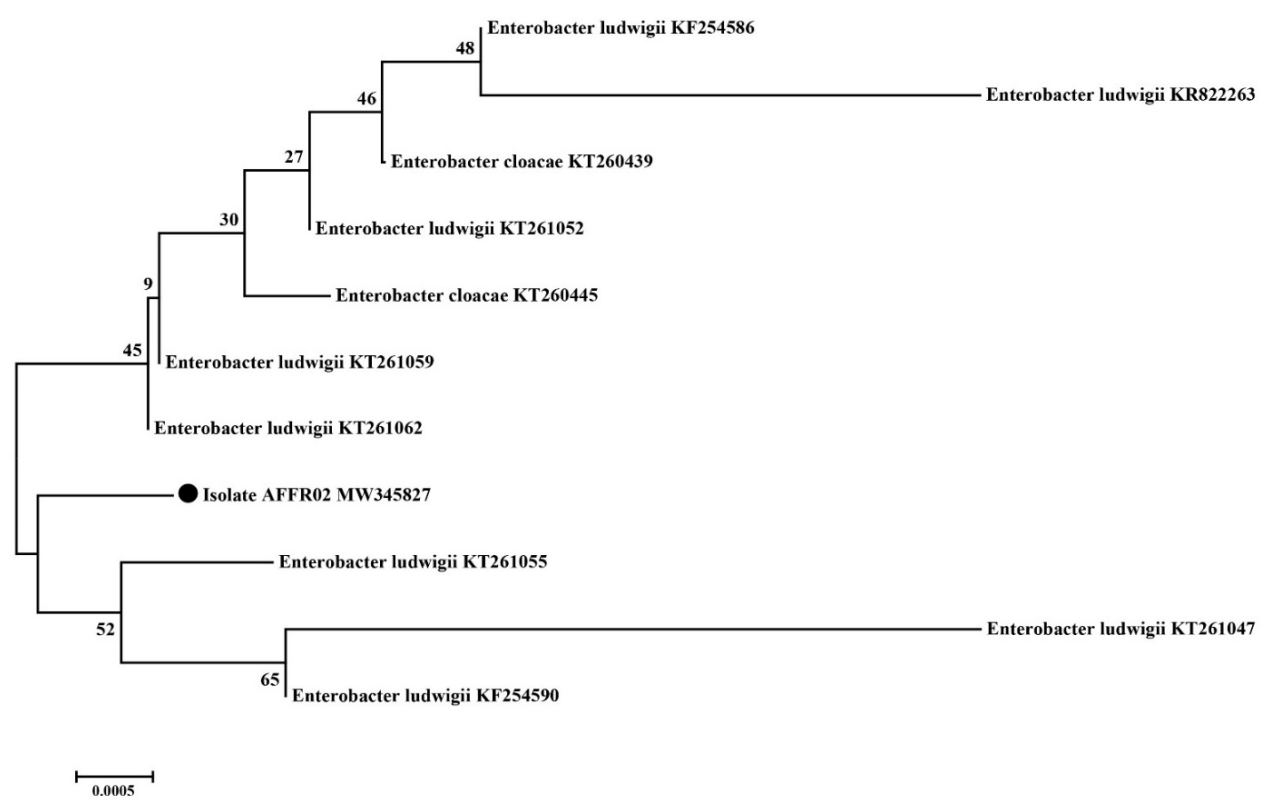

Figure 2. Identification of bacterial isolate AFFR02 using MEGA v.6. Phylogenetic analysis was performed by constructing neighbor-joining trees using a $16 \mathrm{~S}$ rRNA gene sequence. 
Table 1. Effect of isolate AFFR02 and MJ1212 on the growth attributes of alfalfa plants under normal and post-drought stress conditions. Each value in the table is the mean \pm standard deviation of three replicates. Mean in columns followed by different letters describes significant difference by using Duncan's multiple range test at $p>0.05$.

\begin{tabular}{cccccc}
\hline & $\begin{array}{c}\text { Shoot Length } \\
(\mathbf{c m})\end{array}$ & $\begin{array}{c}\text { Root Length } \\
\mathbf{( c m )}\end{array}$ & $\begin{array}{c}\text { Shoot Weight } \\
\mathbf{( g )}\end{array}$ & $\begin{array}{c}\text { Root Weight } \\
\mathbf{( g )}\end{array}$ & $\begin{array}{c}\text { Stalk Diameter } \\
(\mathbf{m m})\end{array}$ \\
\hline \multicolumn{7}{c}{ Control } \\
\hline Control & $20.9 \pm 1.64 \mathrm{a}$ & $16.46 \pm 0.53 \mathrm{~b}$ & $1.33 \pm 0.04 \mathrm{~b}$ & $0.51 \pm 0.025 \mathrm{~b}$ & $2.46 \pm 0.029 \mathrm{~b}$ \\
MJ1212 & $23.6 \pm 0.61 \mathrm{a}$ & $18.08 \pm 0.61 \mathrm{~b}$ & $1.81 \pm 0.06 \mathrm{~b}$ & $0.80 \pm 0.026 \mathrm{~b}$ & $2.88 \pm 0.024 \mathrm{~b}$ \\
AFFR02 & $22.9 \pm 1.12 \mathrm{a}$ & $18.42 \pm 0.37 \mathrm{a}$ & $1.73 \pm 0.18 \mathrm{a}$ & $0.67 \pm 0.028 \mathrm{a}$ & $2.78 \pm 0.037 \mathrm{a}$ \\
\hline & \multicolumn{2}{c}{ Post-drought Stress } \\
\hline Control & $15.7 \pm 0.33 \mathrm{~b}$ & $10.75 \pm 0.39 \mathrm{~b}$ & $0.67 \pm 0.032 \mathrm{c}$ & $0.25 \pm 0.03 \mathrm{~b}$ & $1.16 \pm 0.024 \mathrm{c}$ \\
MJ1212 & $17.92 \pm 0.86 \mathrm{a}$ & $13.4 \pm 0.25 \mathrm{~b}$ & $1.03 \pm 0.018 \mathrm{~b}$ & $0.43 \pm 0.01 \mathrm{~b}$ & $2.08 \pm 0.029 \mathrm{~b}$ \\
AFFR02 & $17.82 \pm 0.82 \mathrm{a}$ & $14.5 \pm 0.21 \mathrm{a}$ & $1.08 \pm 0.016 \mathrm{a}$ & $0.37 \pm 0.01 \mathrm{a}$ & $2.52 \pm 0.028 \mathrm{a}$ \\
\hline
\end{tabular}

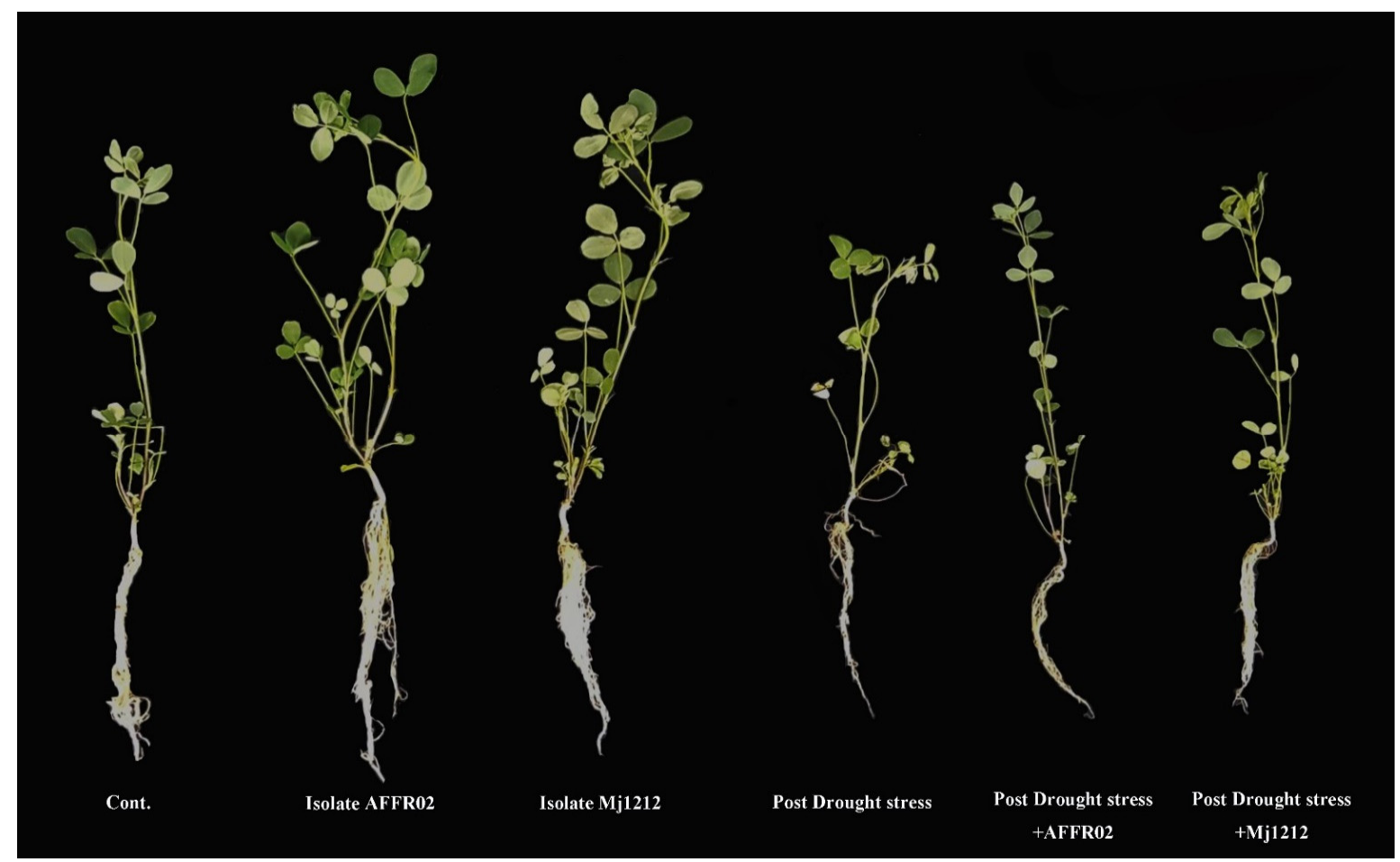

Figure 3. Effect of bacterial isolates AFFR02 and Mj1212 on the growth of alfalfa plants under normal and post-drought stress conditions.

\subsection{Effect of Relative Water Content, Electrolytic Leakage, and Endogenous Abscisic Acid Content} on Alfalfa Plants under Normal and Post-Drought-Stressed Conditions

Water potential content of drought alfalfa showed a great influence in AFFR02- and Mj1212-inoculated plants. Under normal conditions, no significant differences were observed in bacterial-inoculated and control plants. However, in post-drought-stressed alfalfa plants, a significant decrease in RWC was observed (27.45\%). In contrast, an increase in RWC in alfalfa post-drought-stressed plants was observed (24.06\%) compared with post-drought-stressed alfalfa plants (Figure 4A). Similarly, EC results showed a higher level in post-drought-stressed plants (68.87\%) than in control plants. However, a decrease in EC in AFFR02- and Mj1212-inoculated alfalfa post-drought-stressed plants (19.82\%) was observed compared with post-drought-stressed alfalfa plants (Figure 4B). Furthermore, endogenous ABA regulation was observed in post-drought alfalfa plants in AFFR02and Mj1212-inoculated and non-inoculated plants. ABA results showed no difference under normal conditions; however, a significant increase in ABA content $(164.42 \%)$ was observed in post-drought alfalfa plants. A significant decrease in ABA content (24.41\%) 
in bacterial-inoculated plants was observed compared with control post-drought-stressed alfalfa plants (Figure 4C).

Table 2. Effect of isolate AFFR02 and MJ1212 on chlorophyll content (SPAD), chlorophyll A (Chl a), chlorophyll B (Chl b), and total carotenoid (CART) of alfalfa plants under normal and post-drought stress. Each value in the table is the mean \pm standard deviation of three replicates. Mean in columns followed by different letters describes significant difference by using Duncan's multiple range test at $p>0.05$.

\begin{tabular}{ccccc}
\hline & $\begin{array}{c}\text { Chlorophyll } \\
\text { (SPAD) }\end{array}$ & Chl $\boldsymbol{a}$ & Chl $\boldsymbol{b}$ & CART \\
\hline \multicolumn{5}{c}{ Control } \\
\hline Control & $37.5 \pm 1.43 \mathrm{~b}$ & $26.1 \pm 0.96 \mathrm{~b}$ & $22.04 \pm 0.90 \mathrm{~b}$ & $1.1 \pm 0.06 \mathrm{~b}$ \\
MJ1212 & $39.1 \pm 1.16 \mathrm{a}$ & $31.1 \pm 0.54 \mathrm{a}$ & $27.06 \pm 0.54 \mathrm{a}$ & $1.18 \pm 0.02 \mathrm{~b}$ \\
AFFR02 & $39.8 \pm 1.76 \mathrm{a}$ & $31.7 \pm 0.96 \mathrm{a}$ & $27.7 \pm 0.35 \mathrm{a}$ & $1.3 \pm 0.04 \mathrm{a}$ \\
\hline \multicolumn{5}{c}{ Post-Drought Stress } \\
\hline Control & $30.3 \pm 0.61 \mathrm{c}$ & $14.08 \pm 0.88 \mathrm{~b}$ & $12.08 \pm 0.51 \mathrm{~b}$ & $0.51 \pm 0.07 \mathrm{~b}$ \\
MJ1212 & $35.4 \pm 1.71 \mathrm{~b}$ & $17.1 \pm 0.63 \mathrm{a}$ & $15.7 \pm 0.57 \mathrm{a}$ & $0.89 \pm 0.08 \mathrm{a}$ \\
AFFR02 & $37.1 \pm 1.72 \mathrm{a}$ & $17.8 \pm 0.37 \mathrm{a}$ & $15.86 \pm 0.06 \mathrm{a}$ & $0.82 \pm 0.06 \mathrm{a}$ \\
\hline
\end{tabular}
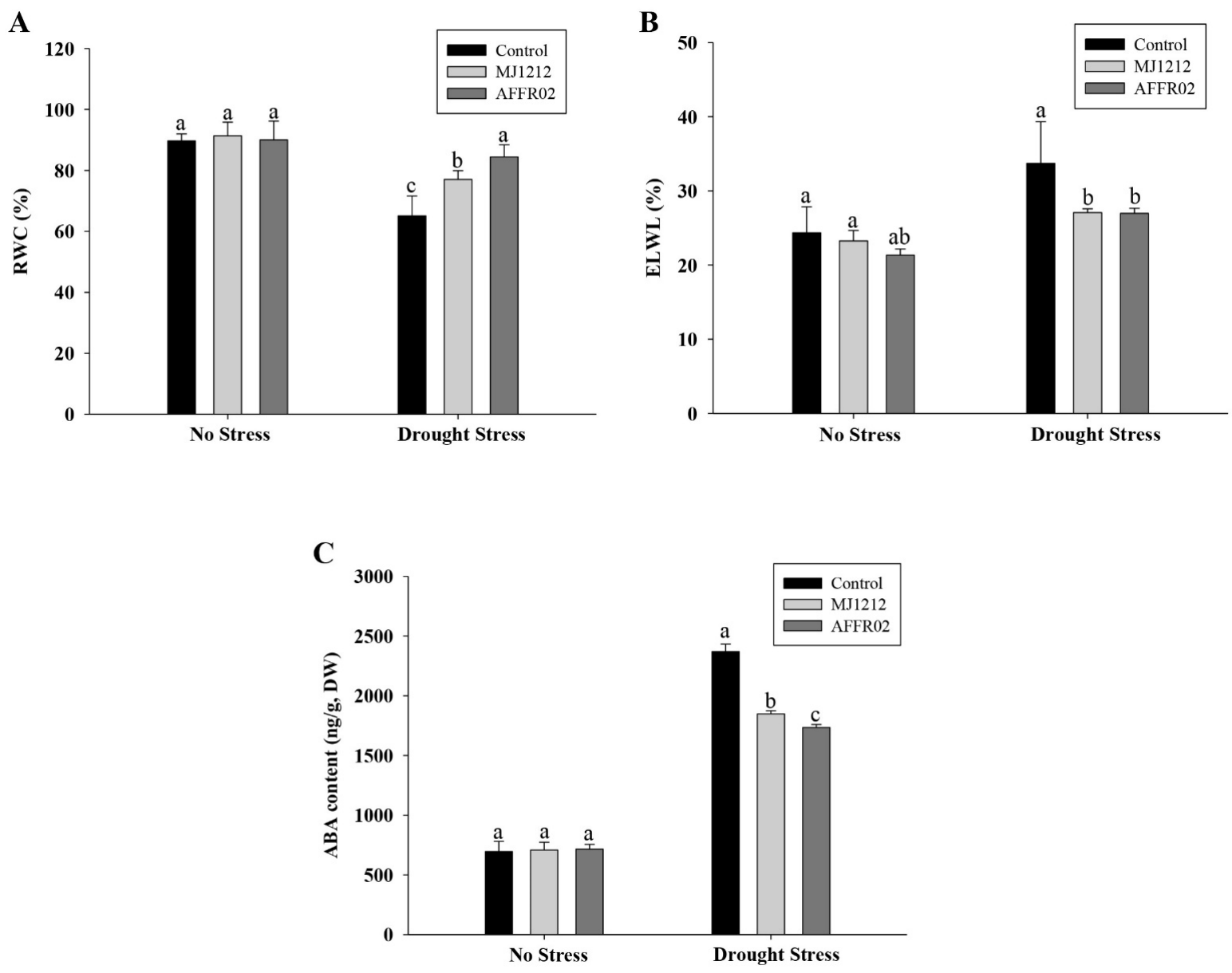

Figure 4. Effect of isolate AFFR02 and MJ1212 on (A) relative water content (RWC), (B) electrolyte leakage (EC), and (C) abscisic acid content (ABA) of alfalfa plants under normal and post-drought stress. The values given are the mean of three replicates and error bars indicate the standard deviation. The bars presented with different letters are significantly different from each other by using Duncan's multiple range test at $p>0.05$. 
3.7. Regulation of Antioxidants in Alfalfa Plants Inoculated with Isolate AFFR02 and Mj1212 under Normal and Post-Drought-Stressed Conditions

Different antioxidants, such as total phenolic content (TPC), DPPH, superoxide dismutase (SOD), and total flavonoid content (TFC) were observed in post-drought-stressed alfalfa, inoculated, and non-inoculated AFFR02 and Mj1212 plants (Figure 5). TPC content was significantly higher in alfalfa post-drought-stressed AFFR02- and Mj1212-inoculated plants $(46.08 \%$ ) than the sole post-drought-stressed and control plants (Figure 5A). DPPH results showed a significant enhancement in DPPH-scavenging activity in post-droughtstressed plants (68.70\%). However, in AFFR02- and Mj1212-inoculated plants, significantly higher scavenging DPPH activity was observed (39.66\%) compared with postdrought-stressed alfalfa plants (Figure 5B). Similarly, SOD (63.72\%) and TFC (77.30\%) content showed no significant difference under normal conditions, whereas an increase in TFC $(13.68 \%)$ and SOD $(28.51 \%)$ content in post-drought-stressed alfalfa plants was observed (Figure 5C,D).

A

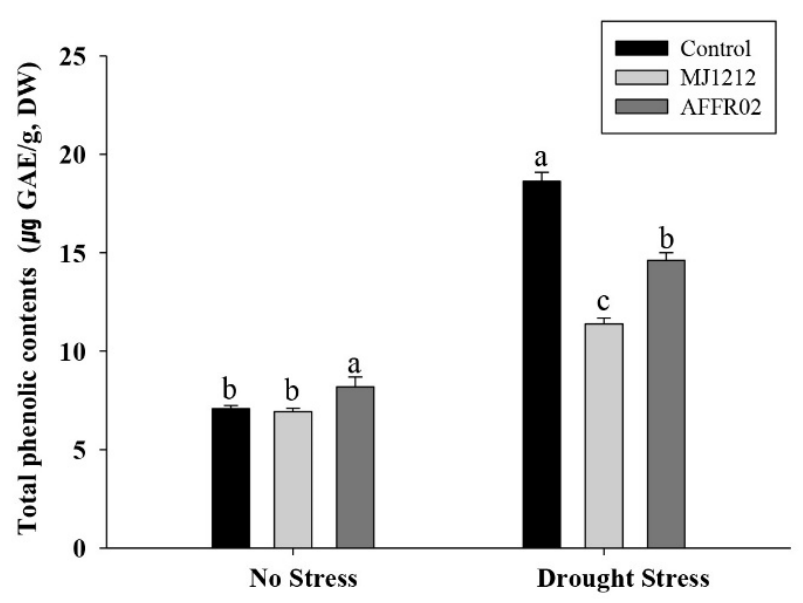

C

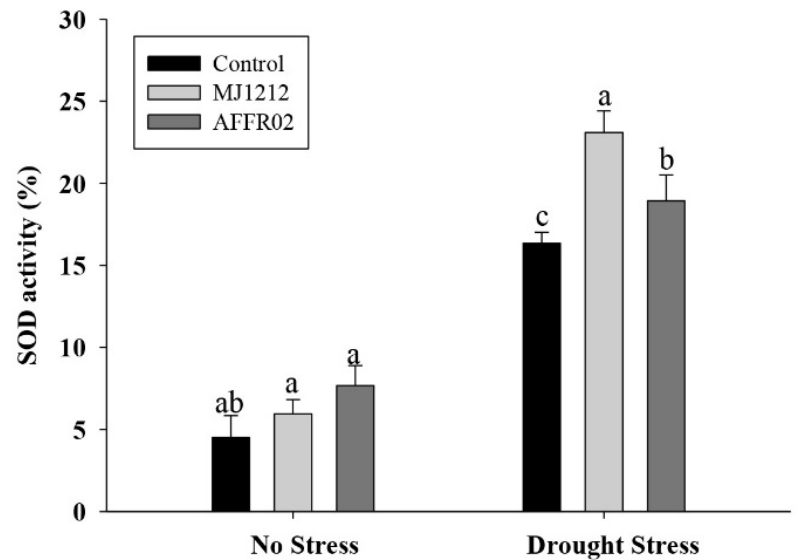

B

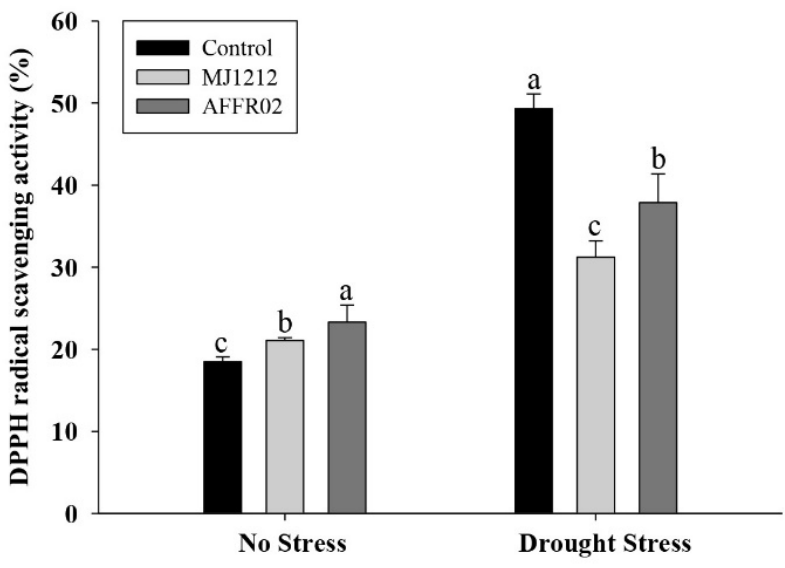

D

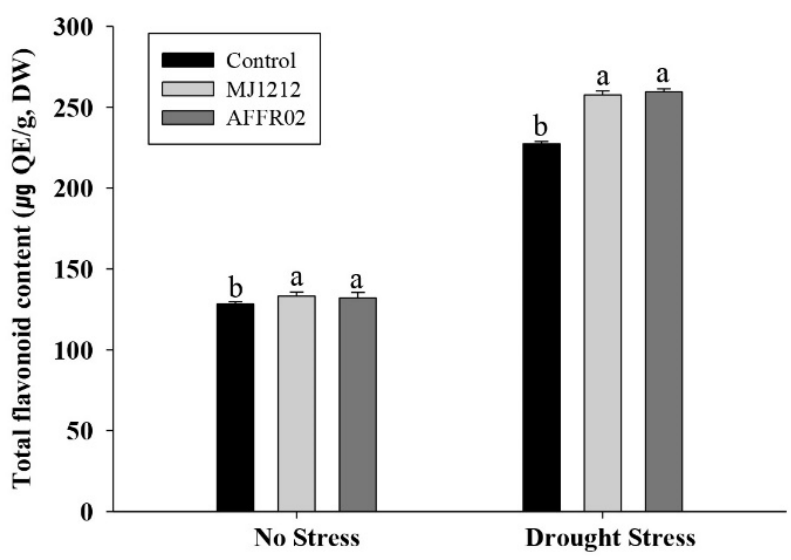

Figure 5. Effect of isolate AFFR02 and MJ1212 on (A) total phenolic content (TPC), (B) DPPH relative scavenging activity, (C) superoxide dismutase (SOD), and (D) total flavonoid content (TFC) of alfalfa plants under normal and post-drought stress. The values given are the mean of three replicates and error bars indicate the standard deviation. The bars presented with different letters are significantly different from each other by using Duncan's multiple range test at $p>0.05$. 


\subsection{Ion Uptake in Alfalfa Plants Inoculated with Isolate AFFR02 and Mj1212 under Normal and} Post-Drought-Stressed Conditions

In this study, ICP analysis of potassium $(\mathrm{K})$, phosphorous $(\mathrm{P})$, calcium $(\mathrm{Ca})$, and magnesium (Mg) was investigated in post-drought alfalfa AFFR02- and Mj1212-inoculated plants (Figure 6). ICP results showed that a decrease in ion uptake; K (31.30\%), P (24.85\%), $\mathrm{Ca}(8.75 \%)$, and $\mathrm{Mg}(21.18 \%)$ content was observed in post-drought-stressed alfalfa plants (Figure 5). However, alfalfa inoculated with AFFR02 and Mj1212 alleviated drought stress and enhanced nutrient uptake; K (17.98\%), P (11.14\%), Ca (3.07\%), and Mg (6.71\%) content were observed in post-drought-stressed inoculated plants (Figure 6).

A

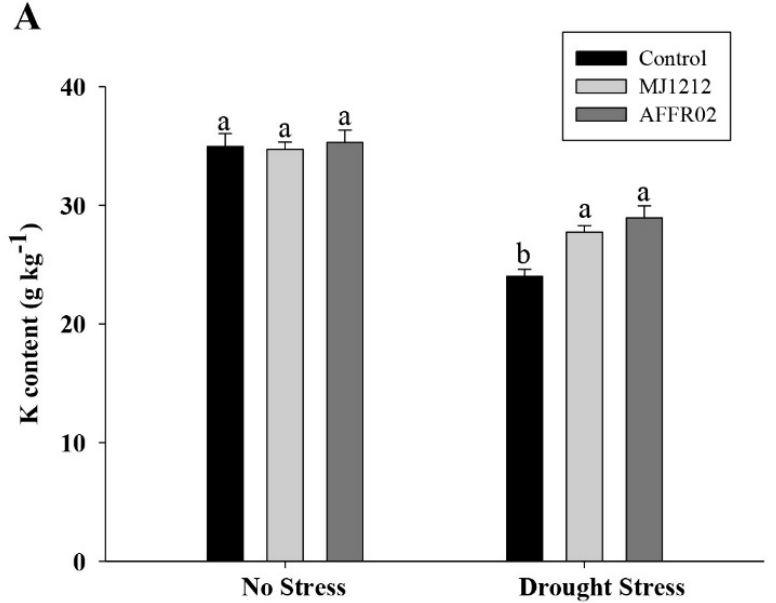

C

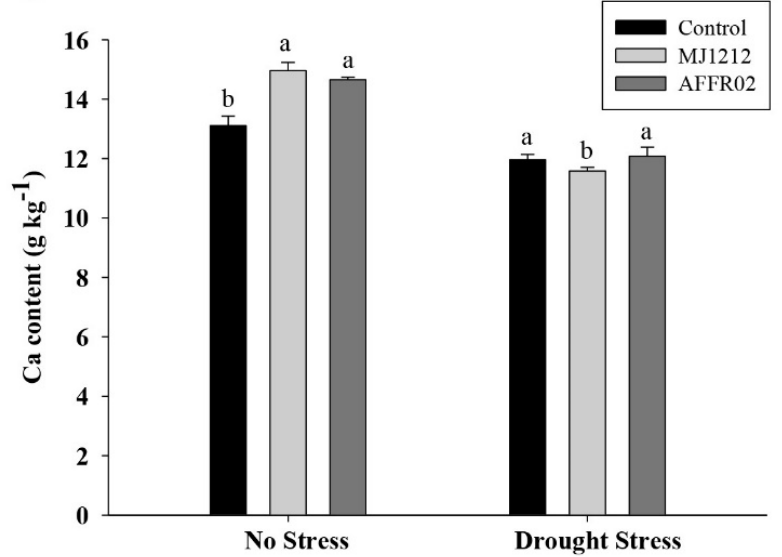

B

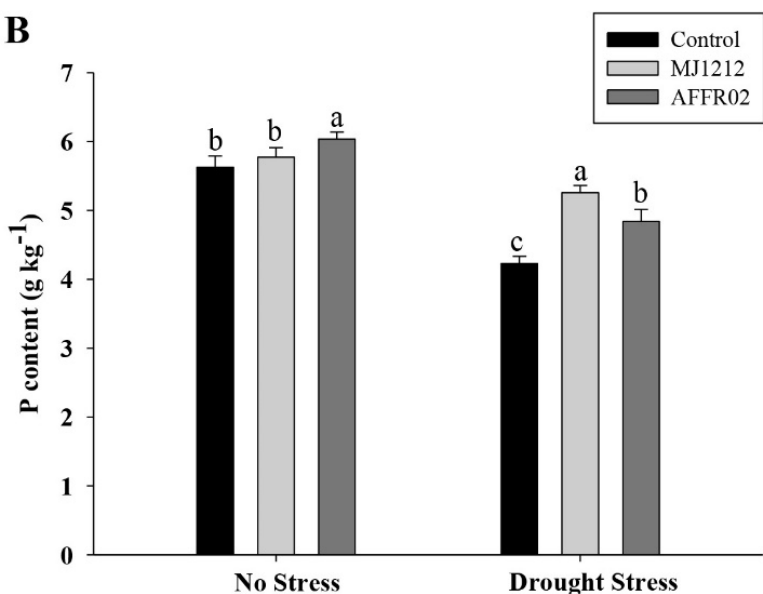

D

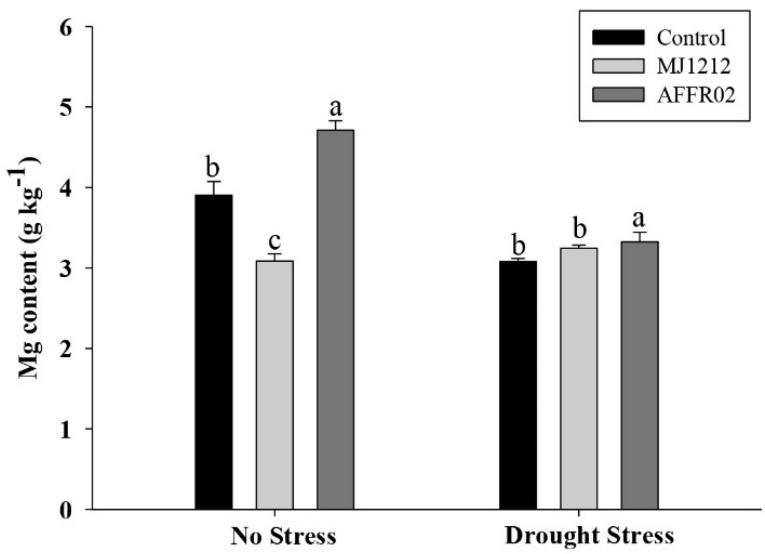

Figure 6. Effect of isolate AFFR02 and MJ1212 on (A) potassium content (K), (B) phosphorous (P), (C) calcium (Ca), and (D) magnesium content $(\mathrm{Mg})$ of alfalfa plants under normal and post-drought stress. The values given are the mean of three replicates and error bars indicate the standard deviation. The bars presented with different letters are significantly different from each other by using Duncan's multiple range test at $p>0.05$.

\section{Discussion}

As previously reported in many studies, drought stress has been recognized as a critical environmental factor that limits plant development and metabolism $[10,39,66]$. The results of this study showed that plant biomass and growth attributes were significantly reduced under drought stress. These results are similar to the findings of Kusaka et al. [67], Chimenti et al. [68], and Erice et al. [69], indicating that drought stress causes a significant reduction in the quality of dry biomass of alfalfa, pearl millet, corn, and broccoli. This reduction in plant biomass may allow these cultivars to maintain RWC by decreasing the size of transpiring organs during drought stress [39]. The mutualistic interaction between plant-microbe interactions can enhance drought stress tolerance by enhancing growth performance. In this experiment, isolate AFFR02 and MJ1212 moderated the adverse 
effect of drought stress and improved plant growth and biomass content in post-drought alfalfa plants (Table 1; Figure 3). Enhancement in the growth attribute's (root/shoot length) biomass (fresh/DW) has been reported in several plants, such as wheat (Azospirillum sp. and Azospirillum brasilense), common bean (Paenibacillus polymyxa and Rhizobium tropici), Arabidopsis (Pirifomospora indica), and broccoli (Variovorax sp.), inoculated with microbes under drought stress [11-13,32,35]. Similarly, CCs are also sensitive to drought stress, and a reduction in CC under drought stress has been reported in several plants, such as broccoli, cucumber, and tomato. In these experiments, $\mathrm{CC}$ decreased under drought stress (Table 2). However, enhancement in CC, Chl a, Chl b, and total carotenoid content were observed in post-drought alfalfa plants inoculated with isolate AFFR02 and MJ1212 (Table 2). Enhancement in the photosynthetic rate and induced change in different ROSscavenging enzymes have been reported in plants inoculated with drought-tolerant isolates, such as Variovorax sp. (broccoli), Bacillus cereus, Bacillus subtilis, Serratia sp. (cucumber), Achromobacter piechaudii (tomato), and Bacillus sp. (corn), which helps the plants cope with drought stress [12,70-72].

Drought stress affects nutrient uptake by impairing the translocation of some nutrients. This investigation of ICP analysis showed that drought stress negatively affects $\mathrm{K}, \mathrm{P}$, $\mathrm{Ca}$, and $\mathrm{Mg}$ content in alfalfa (Figure 6). These results agree with others, indicating that drought stress decreases $\mathrm{Mg}$, P, and other nutrient content in alfalfa [39]. Enhancing nutrient availability through solubilization and chelation of minerals increased nutrient uptake efficiency [33]. P-solubilizing bacteria have attracted attention because of their agroeconomic biotechnological approach and can solubilize more phosphorus under stress $[18,38]$. Phosphorous $(\mathrm{P})$ is a significant macronutrient required for various metabolic processes, such as photosynthesis and respiration. However, less $\mathrm{P}$ is available, and P-solubilizing bacteria can beneficially affect $P$ uptake $[18,38]$. Results of $P$ uptake showed that an increase in AFFR02- and Mj1212-inoculated alfalfa plants might be due to its P-solubilizing activity (Figure 6B).

Similarly, potassium (K) plays an important role in the biochemical and physiological processes of plant growth, and survival of plants under stress [73]. Under drought stress, the diffusion rate of $\mathrm{K}$ in soil toward the roots decreases, depressing plant resistance to drought stress [73]. It was reported by Erdogan et al. [74] that strawberry plants inoculated with three PGPR (Paenibacillus polymyxa, Rhodococcus erythropois, and Pesudomonas fluorescens) mitigate drought stress and enhance nutrient uptake, including K. Furthermore, an increase in $\mathrm{Ca}$ and Mg content was observed in AFFR02- and Mj1212-inoculated alfalfa plants (Figure 6C,D). It was reported that $\mathrm{Ca}$ and $\mathrm{Mg}$ playing a vital role in membrane protection, modulation of ions in the chloroplast, and postponing oxidative damage caused by drought stress $[75,76]$. In plants, $6 \%-25 \%$ of the total chlorophyll plays a vital role in photosynthesis and activation of many enzymes [77]. The decrease in chlorophyll content in post-drought-stressed alfalfa plants might be due to a decrease in Mg content (Figure 6D).

Various environmental stresses, including drought stress, lead to decreased water availability and osmotic stress that promote the synthesis of endogenous ABA phytohormonal regulation and different antioxidant systems $[23,78,79]$. It was also observed that alfalfa plants inoculated with AFFR02 and MJ1212 induced drought stress tolerance by reducing water loss (Figure $4 \mathrm{~A}$ ). This investigation showed that bacterial-inoculated plants had a higher RWC and lower EL than control post-drought-stressed alfalfa plants (Figure 4). A decrease in RWC and an increase in EL indicate a loss of turgor under drought stress, which results in less availability of water to plants [80,81]. In this investigation, lower EL and higher RWC was observed in bacterial-inoculated alfalfa postdrought-stressed plants. Our finding is also supported by other studies that reported that microbial-inoculated plants decrease stress, help fetch higher water content for plants, and decrease stomatal aperture [81-84]. Similarly, the decrease in the EL of post-drought alfalfa-inoculated plants mainly attribute to the integrity and stability of cellular tissue compared with drought-stressed plants. This increase in RWC and decrease in EL was also correlated with stomatal openings regulated by a complex hormonal network, such 
as ABA $[35,84]$. Since the discovery of ABA, several efforts have been devoted to understanding the synthesis of ABA under stress conditions [85-87]. Endogenous ABA level is significantly increased during drought stress by stimulating stomatal closure and adaptive physiological responses [12].

To further elucidate the role of microbes under post-drought stress in alfalfa plants, we investigate different antioxidant effects. Under stress conditions, an increase in damaging levels of ROS is a common factor [88,89]; however, to cope with ROS damage, plants induce enzymatic and nonenzymatic components [90]. SOD acts as a main enzymatic scavenger that scavenges superoxide $\left(\mathrm{O}_{2}{ }^{-}\right)$and hydrogen peroxide $\left(\mathrm{H}_{2} \mathrm{O}_{2}\right)$ to $\mathrm{H}_{2} \mathrm{O}$ and $\mathrm{O}_{2}[3,4,91]$. This study showed that bacterial-inoculated alfalfa plants have higher SOD activities, suggesting inoculated microbe-induced drought tolerance in alfalfa plants (Figure 5C). Furthermore, higher phenolic content, DPPH radicals, and total flavonoids were observed in bacterial-inoculated alfalfa post-drought-stressed plants compared with post-drought-stressed (untreated) plants (Figure 5). This higher accumulation of total phenolic content is essential for maintaining the osmotic potential of plants, increasing physiological activities during drought stress [92] Our results agree with the report of [92-94], who noted that PGPR induction increases phenolic content in wheat and pulse crops. Similarly, Singh et al. [95] and Asghari et al. [96] reported higher antioxidants, such as DPPH in inoculated rice and pennyroyal plants. Alternatively, other antioxidants' total flavonoids play a vital role by eliminating singlet oxygen and alleviating stress [93]. In bacterial-inoculated post-drought-stressed alfalfa plants, higher TFC content was observed (Figure 5D). These results agree with the report of $[93,97]$, who reported an increase in TFC content in Cariniana estrellensis and Cymbopogon citratus bacterial-inoculated drought-stressed plants.

\section{Conclusions}

This investigation showed that the local strain is closely related and identified as Enterobacter ludwigii. It was also observed that drought stress reduced the growth attributes of alfalfa. However, alfalfa plants inoculated with isolate AFFR02 and Mj1212 improved plant capacity to mitigate drought stress. Therefore, based on these results, further studies using genomic approaches to identify field trails of drought-stressed affected areas for their practical applications are needed.

Supplementary Materials: The following are available online at https:/ /www.mdpi.com/article/10 .3390 /agriculture11060485/s1, Figure S1: Growth of bacterial isolates in LB media supplemented with different concentration of polyethylene glycol (PEG) stress $(0 \%, 5 \%, 10 \%$ and $15 \%)$ for 4 days.

Author Contributions: S.-M.K. and L.-R.K. conducted the experiments. E.-H.K., Y.-S.K., K.-Y.K. and J.-J.P. conducted hormonal, antioxidants, and ICP analyses. M.-A.K. and M.H. wrote the manuscript and answered reviewer comments. I.-J.L. designed, supervised, and financed the research. All authors have read and agreed to the published version of the manuscript.

Funding: This study was supported by the Agenda Program (Project No. PJ015026022021) Rural Development Administration, Republic of Korea.

Institutional Review Board Statement: Not applicable.

Informed Consent Statement: Not applicable.

Conflicts of Interest: The authors declare no conflict of interest.

\section{References}

1. Defez, R.; Andreozzi, A.; Dickinson, M.; Charlton, A.; Tadini, L.; Pesaresi, P.; Bianco, C. Improved Drought Stress Response in Alfalfa Plants Nodulated by an IAA Over-producing Rhizobium Strain. Front. Microbiol. 2017, 8, 2466. [CrossRef]

2. Khan, M.A.; Asaf, S.; Khan, A.L.; Jan, R.; Kang, S.-M.; Kim, K.-M.; Lee, I.-J. Rhizobacteria AK1 remediates the toxic effects of salinity stress via regulation of endogenous phytohormones and gene expression in soybean. Biochem. J. 2019, 476, $2393-2409$. [CrossRef] 
3. Khan, M.A.; Asaf, S.; Khan, A.L.; Jan, R.; Kang, S.-M.; Kim, K.-M.; Lee, I.-J. Extending thermotolerance to tomato seedlings by inoculation with SA1 isolate of Bacillus cereus and comparison with exogenous humic acid application. PLoS ONE 2020, 15, e0232228. [CrossRef]

4. Khan, M.A.; Asaf, S.; Khan, A.L.; Jan, R.; Kang, S.-M.; Kim, K.-M.; Lee, I.-J. Thermotolerance effect of plant growth-promoting Bacillus cereus SA1 on soybean during heat stress. BMC Microbiol. 2020, 20, 175. [CrossRef]

5. Li, H.; Wang, Z.; Ke, Q.; Ji, C.Y.; Jeong, J.C.; Lee, H.S.; Lim, Y.P.; Xu, B.; Deng, X.P.; Kwak, S.S. Overexpression of codA gene confers enhanced tolerance to abiotic stresses in alfalfa. Plant. Physiol. Biochem. PPB 2014, 85, 31-40. [CrossRef] [PubMed]

6. Ismail, I.; Hamayun, M.; Hussain, A.; Iqbal, A.; Khan, S.A.; Khan, M.A.; Lee, I.-J. An Endophytic Fungus Gliocladium cibotii Regulates Metabolic and Antioxidant System of Glycine max and Helianthus annuus under Heat Stress. Pol. J. Environ. Stud. 2021, 30, 1631-1640. [CrossRef]

7. Hamayun, M.; Sohn, E.-Y.; Afzal Khan, S.; Shinwari, Z.; Khan, A.; Lee, I.-J. Silicon alleviates the adverse effects of salinity and drought stress on growth and endogenous plant growth hormones of soybean (Glycine max L.). Abstr. Pap. 2010, 42, $1713-1722$.

8. Sahile, A.A.; Khan, M.A.; Hamayun, M.; Imran, M.; Kang, S.-M.; Lee, I.-J. Novel Bacillus cereus Strain, ALT1, Enhance Growth and Strengthens the Antioxidant System of Soybean under Cadmium Stress. Agronomy 2021, 11, 404. [CrossRef]

9. Jan, R.; Khan, M.A.; Asaf, S.; Lubna; Lee, I.-J.; Kim, K.M. Metal Resistant Endophytic Bacteria Reduces Cadmium, Nickel Toxicity, and Enhances Expression of Metal Stress Related Genes with Improved Growth of Oryza Sativa, via Regulating Its Antioxidant Machinery and Endogenous Hormones. Plants 2019, 8, 363. [CrossRef]

10. Azib, S.; Cheloufi, H.; Attab, S.; Bouras, N. Improvement of alfalfa growth under water stress by inoculation with Sinorhizobium meliloti strains from the Algerian Sahara. Int. Sci. Resh. J 2019, 75, 35-43. [CrossRef]

11. Arzanesh, M.H.; Alikhani, H.A.; Khavazi, K.; Rahimian, H.A.; Miransari, M. Wheat (Triticum aestivum L.) growth enhancement by Azospirillum sp. under drought stress. World J. Microbiol. Biotechnol. 2011, 27, 197-205. [CrossRef]

12. Yu-Na, K.; Muhammad Aaqil, K.; Sang-Mo, K.; Muhammad, H.; In-Jung, L. Enhancement of Drought-Stress Tolerance of Brassica oleracea var. italica L. by Newly Isolated Variovorax sp. YNA59. J. Microbiol. Biotechnol. 2020, 30, 1500-1509. [CrossRef]

13. Sherameti, I.; Tripathi, S.; Varma, A.; Oelmüller, R. The Root-Colonizing Endophyte Pirifomospora indica Confers Drought Tolerance in Arabidopsis by Stimulating the Expression of Drought Stress-Related Genes in Leaves. Mol. Plant.-Microbe Interact. ${ }^{\circledR}$ 2008, 21, 799-807. [CrossRef]

14. Ismail, M.H.; Hussain, A.; Khan, S.A.; Iqbal, A.; Lee, I.-J. An endophytic fungus Aspergillus violaceofuscus can be used as heat stress adaptive tool for Glycine max L. and Helianthus annuus L. J. Appl. Bot. Food Qual. 2020, 93, 112.

15. Ciríaco da Silva, E.; Nogueira, R.J.; Silva, M.; Albuquerque, M. Drought Stress and Plant Nutrition. Plant. Stress $2010,5,32-41$.

16. Amtmann, A.; Blatt, M.R. Regulation of macronutrient transport. New Phytol. 2009, 181, 35-52. [CrossRef] [PubMed]

17. Tadayyon, A.; Nikneshan, P.; Pessarakli, M. Effects of drought stress on concentration of macro- and micro-nutrients in Castor (Ricinus communis L.) plant. J. Plant. Nutr. 2018, 41, 304-310. [CrossRef]

18. Kour, D.; Rana, K.L.; Sheikh, I.; Kumar, V.; Yadav, A.N.; Dhaliwal, H.S.; Saxena, A.K. Alleviation of Drought Stress and Plant Growth Promotion by Pseudomonas libanensis EU-LWNA-33, a Drought-Adaptive Phosphorus-Solubilizing Bacterium. Proc. Natl. Acad. Sci. India Sect. B Biol. Sci. 2020, 90, 785-795. [CrossRef]

19. Golldack, D.; Li, C.; Mohan, H.; Probst, N. Tolerance to drought and salt stress in plants: Unraveling the signaling networks. Front. Plant. Sci. 2014, 5, 151. [CrossRef]

20. Zhang, J.Y.; Cruz De Carvalho, M.H.; Torres-Jerez, I.; Kang, Y.; Allen, S.N.; Huhman, D.V.; Tang, Y.; Murray, J.; Sumner, L.W.; Udvardi, M.K. Global reprogramming of transcription and metabolism in M edicago truncatula during progressive drought and after rewatering. Plant Cell Environ. 2014, 37, 2553-2576. [CrossRef]

21. Wang, X.; Cai, X.; Xu, C.; Wang, Q.; Dai, S. Drought-responsive mechanisms in plant leaves revealed by proteomics. Int. J. Mol. Sci. 2016, 17, 1706. [CrossRef] [PubMed]

22. Hamayun, M.; Hussain, A.; Khan, S.A.; Irshad, M.; Khan, A.L.; Waqas, M.; Shahzad, R.; Iqbal, A.; Ullah, N.; Rehman, G.; et al. Kinetin modulates physio-hormonal attributes and isoflavone contents of Soybean grown under salinity stress. Front. Plant. Sci. 2015, 6, 377. [CrossRef] [PubMed]

23. Khan, M.A.; Asaf, S.; Khan, A.L.; Adhikari, A.; Jan, R.; Ali, S.; Imran, M.; Kim, K.-M.; Lee, I.-J. Halotolerant Rhizobacterial Strains Mitigate the Adverse Effects of $\mathrm{NaCl}$ Stress in Soybean Seedlings. BioMed Res. Int. 2019, 2019, 1-15. [CrossRef]

24. Khan, M.A.; Asaf, S.; Khan, A.L.; Ullah, I.; Ali, S.; Kang, S.-M.; Lee, I.-J. Alleviation of salt stress response in soybean plants with the endophytic bacterial isolate Curtobacterium sp. SAK1. Ann. Microbiol. 2019, 69, 797-808. [CrossRef]

25. Sah, S.K.; Reddy, K.R.; Li, J. Abscisic acid and abiotic stress tolerance in crop plants. Front. Plant. Sci. 2016, 7, 571. [CrossRef] [PubMed]

26. Mehrotra, R.; Bhalothia, P.; Bansal, P.; Basantani, M.K.; Bharti, V.; Mehrotra, S. Abscisic acid and abiotic stress tolerance-Different tiers of regulation. J. Plant. Physiol. 2014, 171, 486-496. [CrossRef]

27. Osakabe, Y.; Osakabe, K.; Shinozaki, K.; Tran, L.-S. Response of plants to water stress. Front. Plant. Sci. 2014, 5, 86. [CrossRef] [PubMed]

28. Khan, A.L.; Waqas, M.; Hamayun, M.; Al-Harrasi, A.; Al-Rawahi, A.; Lee, I.-J. Co-synergism of endophyte Penicillium resedanum LK6 with salicylic acid helped Capsicum annuumin biomass recovery and osmotic stress mitigation. BMC Microbiol. 2013, 13, 51. [CrossRef] 
29. Timmusk, S.; Abd El-Daim, I.A.; Copolovici, L.; Tanilas, T.; Kännaste, A.; Behers, L.; Nevo, E.; Seisenbaeva, G.; Stenström, E.; Niinemets, Ü. Drought-Tolerance of Wheat Improved by Rhizosphere Bacteria from Harsh Environments: Enhanced Biomass Production and Reduced Emissions of Stress Volatiles. PLoS ONE 2014, 9, e96086. [CrossRef]

30. Asaf, S.; Khan, A.; Khan, M.; Imran, Q.M.; Yun, B.-W.; Lee, I.-J. Osmoprotective functions conferred to soybean plants via inoculation with Sphingomonas sp. LK11 and exogenous trehalose. Microbiol. Res. 2017, 205, 135-145. [CrossRef]

31. Timmusk, S.; Behers, L.; Muthoni, J.; Muraya, A.; Aronsson, A.-C. Perspectives and challenges of microbial application for crop improvement. Front. Plant. Sci. 2017, 8, 49. [CrossRef] [PubMed]

32. Kim, Y.C.; Glick, B.R.; Bashan, Y.; Ryu, C.M. Enhancement of plant drought tolerance by microbes. In Plant responses to drought stress; Springer: Berlin/Heidelberg, Germany, 2012; pp. 383-413.

33. Bae, H.; Sicher, R.C.; Kim, M.S.; Kim, S.-H.; Strem, M.D.; Melnick, R.L.; Bailey, B.A. The beneficial endophyte Trichoderma hamatum isolate DIS $219 \mathrm{~b}$ promotes growth and delays the onset of the drought response in Theobroma cacao. J. Exp. Bot. 2009, 60, 3279-3295. [CrossRef]

34. Leontidou, K.; Genitsaris, S.; Papadopoulou, A.; Kamou, N.; Bosmali, I.; Matsi, T.; Madesis, P.; Vokou, D.; Karamanoli, K.; Mellidou, I. Plant growth promoting rhizobacteria isolated from halophytes and drought-tolerant plants: Genomic characterisation and exploration of phyto-beneficial traits. Sci. Rep. 2020, 10, 14857. [CrossRef] [PubMed]

35. Figueiredo, M.V.; Burity, H.A.; Martinez, C.R.; Chanway, C.P. Alleviation of drought stress in the common bean (Phaseolus vulgaris L.) by co-inoculation with Paenibacillus polymyxa and Rhizobium tropici. Appl. Soil Ecol. 2008, 40, 182-188. [CrossRef]

36. Kang, S.M.; Adhikari, A.; Lee, K.E.; Khan, M.A.; Khan, A.L.; Shahzad, R.; Dhungana, S.K.; Lee, I.J. Inoculation with Indole-3Acetic Acid-Producing Rhizospheric Rhodobacter sphaeroides KE149 Augments Growth of Adzuki Bean Plants Under Water Stress. J. Microbiol. Biotechnol. 2020, 30, 717-725. [CrossRef]

37. Hamayun, M.; Hussain, A.; Khan, S.A.; Kim, H.-Y.; Khan, A.L.; Waqas, M.; Irshad, M.; Iqbal, A.; Rehman, G.; Jan, S.; et al. Gibberellins Producing Endophytic Fungus Porostereum spadiceum AGH786 Rescues Growth of Salt Affected Soybean. Front. Microbiol. 2017, 8, 686. [CrossRef]

38. Kour, D.; Rana, K.L.; Yadav, A.N.; Yadav, N.; Kumar, V.; Kumar, A.; Sayyed, R.Z.; Hesham, A.E.-L.; Dhaliwal, H.S.; Saxena, A.K. Drought-Tolerant Phosphorus-Solubilizing Microbes: Biodiversity and Biotechnological Applications for Alleviation of Drought Stress in Plants. In Plant Growth Promoting Rhizobacteria for Sustainable Stress Management: Volume 1: Rhizobacteria in Abiotic Stress Management; Sayyed, R.Z., Arora, N.K., Reddy, M.S., Eds.; Springer: Singapore, 2019; pp. 255-308.

39. Abid, M.; Mansour, E.; Yahia, L.B.; Bachar, K.; Ben Khaled, A.; Ferchichi, A. Alfalfa nutritive quality as influenced by drought in South-Eastern Oasis of Tunisia. Ital. J. Anim. Sci. 2016, 15, 334-342. [CrossRef]

40. Annicchiarico, P.; Barrett, B.; Brummer, E.C.; Julier, B.; Marshall, A.H. Achievements and Challenges in Improving Temperate Perennial Forage Legumes. Crit. Rev. Plant. Sci. 2015, 34, 327-380. [CrossRef]

41. Putnam, D.; Russelle, M.; Orloff, S.; Kuhn, J.; Fitzhugh, L.; Godfrey, L.; Kiess, A.; Long, R. Alfalfa Wildlife and the EnvironmentThe Importance and Benefits of Alfalfa in the 21st Century. CA Forage Assoc. Novato CA. 2001, 1-24. Available online: http: / / agric.ucdavis.edu/files/242006.pdf (accessed on 23 May 2021).

42. Kumar, T.; Bao, A.-K.; Bao, Z.; Wang, F.; Gao, L.; Wang, S.-M. The progress of genetic improvement in alfalfa (Medicago sativa L.). Czech. J. Genet. Plant. Breed. 2018, 54,41-51. [CrossRef]

43. Jia, H.; Wang, X.; Shi, Y.; Wu, X.; Wang, Y.; Liu, J.; Fang, Z.; Li, C.; Dong, K. Overexpression of Medicago sativa LEA4-4 can improve the salt, drought, and oxidation resistance of transgenic Arabidopsis. PLoS ONE 2020, 15, e0234085. [CrossRef]

44. Zheng, G.; Fan, C.; Di, S.; Wang, X.; Xiang, C.; Pang, Y. Over-Expression of Arabidopsis EDT1 Gene Confers Drought Tolerance in Alfalfa (Medicago sativa L.). Front. Plant. Sci. 2017, 8. [CrossRef] [PubMed]

45. Bouizgaren, A.; Farissi, M.; Ghoulam, C.; Kallida, R.; Faghire, M.; Barakate, M.; Al Feddy, M.N. Assessment of summer drought tolerance variability in Mediterranean alfalfa (Medicago sativa L.) cultivars under Moroccan fields conditions. Arch. Agron. Soil Sci. 2013, 59, 147-160. [CrossRef]

46. Rao, S.; Qayyum, A.; Razzaq, A.; Ahmad, M.; Mahmood, I.; Sher, A. Role of foliar application of salicylic acid and L-tryptophan in drought tolerance of maize. J. Anim. Plant. Sci. 2012, 22, 768-772.

47. Tariq, A.; Pan, K.; Olatunji, O.A.; Graciano, C.; Li, Z.; Sun, F.; Zhang, L.; Wu, X.; Chen, W.; Song, D.; et al. Phosphorous fertilization alleviates drought effects on Alnus cremastogyne by regulating its antioxidant and osmotic potential. Sci. Rep. 2018, 8, 5644. [CrossRef] [PubMed]

48. Usmani, M.M.; Nawaz, F.; Majeed, S.; Shehzad, M.A.; Ahmad, K.S.; Akhtar, G.; Aqib, M.; Shabbir, R.N. Sulfate-mediated Drought Tolerance in Maize Involves Regulation at Physiological and Biochemical Levels. Sci. Rep. 2020, 10, 1147. [CrossRef] [PubMed]

49. Kang, S.-M.; Khan, A.L.; Waqas, M.; You, Y.-H.; Kim, J.-H.; Kim, J.-G.; Hamayun, M.; Lee, I.-J. Plant growth-promoting rhizobacteria reduce adverse effects of salinity and osmotic stress by regulating phytohormones and antioxidants in Cucumis sativus. J. Plant. Interact. 2014, 9, 673-682. [CrossRef]

50. Bharti, N.; Yadav, D.; Barnawal, D.; Maji, D.; Kalra, A. Exiguobacterium oxidotolerans, a halotolerant plant growth promoting rhizobacteria, improves yield and content of secondary metabolites in Bacopa monnieri (L.) Pennell under primary and secondary salt stress. World J. Microbiol. Biotechnol. 2013, 29, 379-387. [CrossRef]

51. Cakmakci, R.; Dönmez, M.F.; Erdoğan, Ü. The effect of plant growth promoting rhizobacteria on barley seedling growth, nutrient uptake, some soil properties, and bacterial counts. Turk. J. Agric. For. 2007, 31, 189-199. 
52. Kang, S.-M.; Hamayun, M.; Joo, G.-J.; Khan, A.L.; Kim, Y.-H.; Kim, S.-K.; Jeong, H.-J.; Lee, I.-J. Effect of Burkholderia sp. KCTC 11096BP on some physiochemical attributes of cucumber. Eur. J. Soil Biol. 2010, 46, 264-268. [CrossRef]

53. Khan, M.A.; Ullah, I.; Waqas, M.; Hamayun, M.; Khan, A.L.; Asaf, S.; Kang, S.-M.; Kim, K.-M.; Jan, R.; Lee, I.-J. Halo-tolerant rhizospheric Arthrobacter woluwensis AK1 mitigates salt stress and induces physio-hormonal changes and expression of GmST1 and GmLAX3 in soybean. Symbiosis 2019, 77, 9-21. [CrossRef]

54. Kang, S.-M.; Asaf, S.; Khan, A.L.; Khan, A.; Mun, B.-G.; Khan, M.A.; Gul, H.; Lee, I.-J. Complete Genome Sequence of Pseudomonas psychrotolerans CS51, a Plant Growth-Promoting Bacterium, Under Heavy Metal Stress Conditions. Microorganisms 2020, 8, 382. [CrossRef] [PubMed]

55. Adhikari, A.; Khan, M.A.; Lee, K.E.; Kang, S.M.; Dhungana, S.K.; Bhusal, N.; Lee, I.J. The Halotolerant RhizobacteriumPseudomonas koreensis MU2 Enhances Inorganic Silicon and Phosphorus Use Efficiency and Augments Salt Stress Tolerance in Soybean (Glycine max L.). Microorganisms 2020, 8, 1256. [CrossRef] [PubMed]

56. Adhikari, A.; Lee, K.-E.; Khan, M.A.; Kang, S.-M.; Adhikari, B.; Imran, M.; Jan, R.; Kim, K.-M.; Lee, I.-J. Effect of Silicate and Phosphate Solubilizing Rhizobacterium Enterobacter ludwigii GAK2 on Oryza sativa L. under Cadmium Stress. J. Microbiol. Biotechnol. 2020, 30, 118-126. [CrossRef] [PubMed]

57. Kang, S.M.; Radhakrishnan, R.; You, Y.H.; Lee, K.E.; Kim, J.; Joo, G.J.; Kim, J.G.; Lee, I. Mustard and Chinese cabbage plant growth promotion by optimal-medium-cultured acinetobacter calcoaceticus SE370. J. Pure Appl. Microbiol. 2016, 10, $1693-1699$.

58. Kang, S.M.; Radhakrishnan, R.; You, Y.H.; Joo, G.J.; Lee, I.J.; Lee, K.E.; Kim, J.H. Phosphate Solubilizing Bacillus megaterium mj1212 Regulates Endogenous Plant Carbohydrates and Amino Acids Contents to Promote Mustard Plant Growth. Indian J. Microbiol. 2014, 54, 427-433. [CrossRef]

59. Khan, M.A.; Sahile, A.A.; Jan, R.; Asaf, S.; Hamayun, M.; Imran, M.; Adhikari, A.; Kang, S.-M.; Kim, K.-M.; Lee, I.-J. Halotolerant bacteria mitigate the effects of salinity stress on soybean growth by regulating secondary metabolites and molecular responses. BMC Plant. Biol. 2021, 21, 176. [CrossRef] [PubMed]

60. Asaf, S.; Hamayun, M.; Khan, A.L.; Waqas, M.; Khan, M.A.; Jan, R.; Lee, I.-J.; Hussain, A. Salt tolerance of Glycine max.L induced by endophytic fungus Aspergillus flavus CSH1, via regulating its endogenous hormones and antioxidative system. Plant. Physiol. Biochem. 2018, 128, 13-23. [CrossRef] [PubMed]

61. Khan, M.A.; Hamayun, M.; Iqbal, A.; Khan, S.A.; Hussain, A.; Asaf, S.; Khan, A.L.; Yun, B.-W.; Lee, I.-J. Gibberellin application ameliorates the adverse impact of short-term flooding on Glycine max L. Biochem. J. 2018, 475, 2893-2905. [CrossRef]

62. Asaf, S.; Khan, M.; Khan, A.; Waqas, M.; Shahzad, R.; Kim, A.-Y.; Kang, S.-M.; Lee, I.-J. Bacterial endophytes from arid land plants regulate endogenous hormone content and promote growth in crop plants: An example of Sphingomonas sp. and Serratia marcescens. J. Plant. Interact. 2017, 12, 31-38. [CrossRef]

63. Adhikari, B.; Dhungana, S.K.; Ali, M.W.; Adhikari, A.; Kim, I.-D.; Shin, D.-H. Resveratrol, total phenolic and flavonoid contents, and antioxidant potential of seeds and sprouts of Korean peanuts. Food Sci. Biotechnol. 2018, 27, 1275-1284. [CrossRef]

64. Blois, M.S. Antioxidant determinations by the use of a stable free radical. Nature 1958, 181, 1199-1200. [CrossRef]

65. Kang, S.-M.; Shahzad, R.; Khan, M.A.; Hasnain, Z.; Lee, K.-E.; Park, H.-S.; Kim, L.-R.; Lee, I.-J. Ameliorative effect of indole-3acetic acid- and siderophore-producing Leclercia adecarboxylata MO1 on cucumber plants under zinc stress. J. Plant. Interact. 2021, 16, 30-41. [CrossRef]

66. Marulanda, A.; Azcon, R.; Ruiz-Lozano, J.M. Contribution of six arbuscular mycorrhizal fungal isolates to water uptake by Lactuca sativa plants under drought stress. Physiol. Plant. 2003, 119, 526-533. [CrossRef]

67. Kusaka, M.; Lalusin, A.G.; Fujimura, T. The maintenance of growth and turgor in pearl millet (Pennisetum glaucum [L.] Leeke) cultivars with different root structures and osmo-regulation under drought stress. Plant. Sci. 2005, 168, 1-14. [CrossRef]

68. Chimenti, C.A.; Marcantonio, M.; Hall, A. Divergent selection for osmotic adjustment results in improved drought tolerance in maize (Zea mays L.) in both early growth and flowering phases. Field Crop. Res. 2006, 95, 305-315. [CrossRef]

69. Erice, G.; Louahlia, S.; Irigoyen, J.J.; Sanchez-Diaz, M.; Avice, J.-C. Biomass partitioning, morphology and water status of four alfalfa genotypes submitted to progressive drought and subsequent recovery. J. Plant Physiol. 2010, 167, 114-120. [CrossRef] [PubMed]

70. Wang, C.-J.; Yang, W.; Wang, C.; Gu, C.; Niu, D.-D.; Liu, H.-X.; Wang, Y.-P.; Guo, J.-H. Induction of Drought Tolerance in Cucumber Plants by a Consortium of Three Plant Growth-Promoting Rhizobacterium Strains. PLoS ONE 2012, 7, e52565. [CrossRef]

71. Mayak, S.; Tirosh, T.; Glick, B.R. Plant growth-promoting bacteria that confer resistance to water stress in tomatoes and peppers. Plant. Sci. 2004, 166, 525-530. [CrossRef]

72. Vardharajula, S.; Zulfikar Ali, S.; Grover, M.; Reddy, G.; Bandi, V. Drought-tolerant plant growth promoting Bacillus spp.: Effect on growth, osmolytes, and antioxidant status of maize under drought stress. J. Plant. Interact. 2011, 6, 1-14. [CrossRef]

73. Wang, M.; Zheng, Q.; Shen, Q.; Guo, S. The Critical Role of Potassium in Plant Stress Response. Int. J. Mol. Sci. 2013, 14, 7370-7390. [CrossRef] [PubMed]

74. Erdogan, U.; Çakmakçi, R.; Varmazyarı, A.; Turan, M.; Erdogan, Y.; Kıtır, N. Role of inoculation with multi-trait rhizobacteria on strawberries under water deficit stress. Zemdirb. Agric. 2016, 103, 67-76. [CrossRef]

75. Armada, E.; Leite, M.F.A.; Medina, A.; Azcón, R.; Kuramae, E.E. Native bacteria promote plant growth under drought stress condition without impacting the rhizomicrobiome. FEMS Microbiol. Ecol. 2018, 94. [CrossRef]

76. Abass, M.; Moradtalab, N.; Abd-Allah, E.; Ahmad, P.; Hajiboland, R. Plant growth under drought stress: Significance of mineral nutrients. Water Stress Crop. Plants Sustain. Approach 2016, 2, 649-668. 
77. Slamka, P.; Krček, M.; Golisová, A. Concentration of magnesium and its uptake by aboveground phytomass of spring barley (Hordeum vulgare L.) grown under drought stress condition. Res. J. Agric. Sci. 2011, 43, 198-205.

78. Kim, T.-H.; Böhmer, M.; Hu, H.; Nishimura, N.; Schroeder, J.I. Guard cell signal transduction network: Advances in understanding abscisic acid, CO2, and Ca2+ signaling. Annu. Rev. Plant. Biol. 2010, 61, 561-591. [CrossRef] [PubMed]

79. Khan, M.A.; Asaf, S.; Khan, A.L.; Adhikari, A.; Jan, R.; Ali, S.; Imran, M.; Kim, K.M.; Lee, I.J. Plant growth-promoting endophytic bacteria augment growth and salinity tolerance in rice plants. Plant. Biol. 2020, 22, 850-862. [CrossRef] [PubMed]

80. Roger, M.J.R. Handbook of Plant Ecophysiology Techniques; Springer, Kluwer Academic Publishers: Berlin/Heidelberg, Germany, 2001; pp. 207-212.

81. Khan, A.L.; Hamayun, M.; Ahmad, N.; Waqas, M.; Kang, S.-M.; Kim, Y.-H.; Lee, I.-J. Exophiala sp. LHL08 reprograms Cucumis sativus to higher growth under abiotic stresses. Physiol. Plant. 2011, 143, 329-343. [CrossRef] [PubMed]

82. Porcel, R.; Ruiz-Lozano, J.M. Arbuscular mycorrhizal influence on leaf water potential, solute accumulation, and oxidative stress in soybean plants subjected to drought stress. J. Exp. Bot. 2004, 55, 1743-1750. [CrossRef]

83. Khalvati, M.; Bartha, B.; Dupigny, A.; Schröder, P. Arbuscular mycorrhizal association is beneficial for growth and detoxification of xenobiotics of barley under drought stress. J. Soils Sediments 2010, 10, 54-64. [CrossRef]

84. Cho, S.M.; Kang, B.R.; Han, S.H.; Anderson, A.J.; Park, J.-Y.; Lee, Y.-H.; Cho, B.H.; Yang, K.-Y.; Ryu, C.-M.; Kim, Y.C. 2R, 3R-butanediol, a bacterial volatile produced by Pseudomonas chlororaphis O6, is involved in induction of systemic tolerance to drought in Arabidopsis thaliana. Mol. Plant.-Microbe Interact. 2008, 21, 1067-1075. [CrossRef] [PubMed]

85. Xiong, L.; Zhu, J.K. Regulation of abscisic acid biosynthesis. Plant Physiol. 2003, 133, 29-36. [CrossRef] [PubMed]

86. Kang, S.-M.; Khan, A.L.; Waqas, M.; Asaf, S.; Lee, K.-E.; Park, Y.-G.; Kim, A.-Y.; Khan, M.A.; You, Y.-H.; Lee, I.-J. Integrated phytohormone production by the plant growth-promoting rhizobacterium Bacillus tequilensis SSB07 induced thermotolerance in soybean. J. Plant. Interact. 2019, 14, 416-423. [CrossRef]

87. Kang, S.-M.; Shahzad, R.; Bilal, S.; Khan, A.L.; Park, Y.-G.; Lee, K.-E.; Asaf, S.; Khan, M.A.; Lee, I.-J. Indole-3-acetic-acid and ACC deaminase producing Leclercia adecarboxylata MO1 improves Solanum lycopersicum L. growth and salinity stress tolerance by endogenous secondary metabolites regulation. BMC Microbiol. 2019, 19, 80. [CrossRef] [PubMed]

88. Apel, K.; Hirt, H. Reactive oxygen species: Metabolism, oxidative stress, and signal transduction. Annu. Rev. Plant. Biol. 2004, 55, 373-399. [CrossRef] [PubMed]

89. Ullah, I.; Waqas, M.; Khan, M.A.; Lee, I.-J.; Kim, W.-C. Exogenous ascorbic acid mitigates flood stress damages of Vigna angularis. Appl. Biol. Chem. 2017, 60, 603-614. [CrossRef]

90. Mastouri, F.; Björkman, T.; Harman, G.E. Trichoderma harzianum enhances antioxidant defense of tomato seedlings and resistance to water deficit. Mol. Plant.-Microbe Interact. MPMI 2012, 25, 1264-1271. [CrossRef]

91. Habib, S.H.; Kausar, H.; Saud, H.M. Plant Growth-Promoting Rhizobacteria Enhance Salinity Stress Tolerance in Okra through ROS-Scavenging Enzymes. Biomed. Res. Int. 2016, 2016, 6284547. [CrossRef]

92. Saikia, J.; Sarma, R.K.; Dhandia, R.; Yadav, A.; Bharali, R.; Gupta, V.K.; Saikia, R. Alleviation of drought stress in pulse crops with ACC deaminase producing rhizobacteria isolated from acidic soil of Northeast India. Sci. Rep. 2018, 8, 3560. [CrossRef]

93. Tiepo, A.N.; Constantino, L.V.; Madeira, T.B.; Gonçalves, L.S.A.; Pimenta, J.A.; Bianchini, E.; de Oliveira, A.L.M.; Oliveira, H.C.; Stolf-Moreira, R. Plant growth-promoting bacteria improve leaf antioxidant metabolism of drought-stressed Neotropical trees. Planta 2020, 251, 83. [CrossRef]

94. Khan, N.; Bano, A. Exopolysaccharide producing rhizobacteria and their impact on growth and drought tolerance of wheat grown under rainfed conditions. PLoS ONE 2019, 14, e0222302. [CrossRef] [PubMed]

95. Singh, D.P.; Singh, V.; Gupta, V.K.; Shukla, R.; Prabha, R.; Sarma, B.K.; Patel, J.S. Microbial inoculation in rice regulates antioxidative reactions and defense related genes to mitigate drought stress. Sci. Rep. 2020, 10, 4818. [CrossRef] [PubMed]

96. Asghari, B.; Khademian, R.; Sedaghati, B. Plant growth promoting rhizobacteria (PGPR) confer drought resistance and stimulate biosynthesis of secondary metabolites in pennyroyal (Mentha pulegium L.) under water shortage condition. Sci. Hortic. 2020, 263, 109132. [CrossRef]

97. Mirzaei, M.; Ladan Moghadam, A.; Hakimi, L.; Danaee, E. Plant growth promoting rhizobacteria (PGPR) improve plant growth, antioxidant capacity, and essential oil properties of lemongrass (Cymbopogon citratus) under water stress. Iran. J. Plant. Physiol. 2020, 10, 3155-3166. 